\title{
Laser Land Levelling- An Engineering Approach for Scientific Irrigation Water Management in Irrigation Command Areas of Karnataka, India
}

\author{
P. S. Kanannavar ${ }^{1 *}$, B. D. Premanand ${ }^{2}$, B. Subhas ${ }^{3}$, \\ B. Anuraja ${ }^{3}$ and P. Basavaraj Bhogi ${ }^{4}$ \\ ${ }^{1}$ (Agri. Engg.), IWMRC, Belavatagi, \\ University of Agricultural Sciences, Dharwad, India \\ ${ }^{2}$ (Agri. Engg.) (UAS Bangalore), India \\ ${ }^{3}$ (Agri. Engg.) (UAS Dharwad), India \\ ${ }^{4}$ (Agri. Engg.) (UAHS Shivamogga), India
}

*Corresponding author

\section{A B S T R A C T}

\begin{tabular}{|l||}
\hline Ke y w o r d s \\
Resource \\
management, Laser \\
levelling, Precision \\
agriculture, Land \\
development, \\
Command area \\
\hline Article Info \\
\hline $\begin{array}{l}\text { Accepted: } \\
18 \text { April } 2020 \\
\text { Available Online: } \\
\text { 10 May } 2020\end{array}$ \\
\hline
\end{tabular}

Management of two critical and important resources viz., Land and water in agriculture has become a challenging task for many reasons. In rainfed and irrigated agriculture, land development plays a key role because of undulating topography of the soil surface. It has a major impact on the germination, water saving and crop yield. Conventional methods of land levelling are more cumbersome and not so precise and repetitive in nature and mainly depend on the skills of the driver. A significant (20-25\%) amount of irrigation water is lost during its application at the farm due to poor farm design and unevenness of the field. Unscientific and excessive irrigation is leading to degraded soil health because of water logging and salinity in almost all command areas of Karnataka. Scientific land levelling which can give a required slope depending on the soil type, saves irrigation water and facilitates field operation, conserves vital resources and increases the yield. The recent technology of laser land levelling can address these important issues and help to accomplish yield increase and agricultural sustainability in Karnataka. The studies on engineering approach of laser land levelling technology taken up for the first time in Karnataka during 2008-09 in the jurisdiction of the University of Agricultural Sciences, Raichur highlighted considerable reduction in drudgery of land levelling, higher levelling index, higher uniformity in soil-moisture distribution. It was observed that 25 to $35 \%$ increase in paddy yield and water saving (25-30\%), 30$40 \%$ labour saving and 30 to $40 \%$ saving in energy requirement in paddy cultivation.

\section{Introduction}

In agriculture, land development and irrigation play a key role because undulating topography of the soil surface has a major impact on the germination, water saving and crop yield. Irrigation is one of the agricultural operations performed in crop production system. India supports $17.5 \%$ of world population with $4 \%$ of world water resource and $2.3 \%$ of world land area. Conventionally farmers irrigate their crop by flooding the 
field i.e. surface irrigation is practiced especially for the major crops like rice and wheat. The irrigation efficiencies of surface irrigation method through canal irrigated areas are reported to be $22 \%$ in Rabi season and 35\% in Kharif season (Bosu, 2010). Studies have indicated that significant amount of (20-25\%) of irrigation water is lost during flooding due to poor farm designs and unevenness of the fields. In the context of climate change with the shrinking available water and energy resources, judicious application of irrigation water is of utmost importance.

Therefore in agriculture, land development plays a key role because undulating topography of the soil surface has a major impact on the germination, water saving and crop yield. Traditional methods of land levelling are more cumbersome and not so precise and repetitive in nature and mainly depend on the skills of the driver. The technological improvements and interventions in Indian agriculture can bring about revolutionary changes in agricultural production.

Scientific laser levelling technology saves irrigation water and facilitates field operation, conserves vital resources and increases the yield (Rickman, 2002). The latest laser technology of land levelling was studied at UAS Raichur. Through extension measures the laser technology was taken to paddy farmers of Hyderabad-Karnataka region and found that it could address these important issues and help to accomplish yield increase, energy saving and agricultural sustainability.

Laser land levelling technology was demonstrated to the farmers during Krishimelas every year and field level trainings. After demonstrations in paddy fields of Upper Krishna Project (UKP) and Tungabhadra Project (TBP) command areas and through field level adoption. It was observed that 25 to $35 \%$ increase in paddy yield and water saving (25-30\%), 30-40\% labour saving and 30 to $40 \%$ saving in energy requirement in paddy cultivation. Even research findings on effect of laser land levelling in groundnut production in respect of crop growth, yield and water saving are quite encouraging.

So far several thousand acres of fields are developed with this engineering approach. Procurement of laser levellers, experimentation in all State Agriculture Universities (SAUs) and adoption of laser levelling in large scale would be a successful and significant contribution of all SAUs in the field of Precision Agriculture in Karnataka for enhanced water productivity.

Thus, latest resource conservation technology (RCT) of laser land levelling in agriculture offers a pragmatic solution to protect, manage and effective utilization of natural resources viz., land and water for sustainable agriculture. In this context there is huge opportunity and need to promote scientific Laser technology in rainfed and especially in all irrigated command areas of entire Karnataka to address future challenges of agricultural production by conserving soil and water resources in a scientific manner.

\section{Materials and Methods}

Adoption of Laser technology in agriculture fields of Karnataka was started with procurement of Laser guided land leveller from Spectra Precision Pvt., Ltd New Delhi in the year 2008-09 by UAS Raichur. For the first time in Karnataka a study was initiated to find the feasibility and benefits of laser technology in the research farms of UAS, Raichur. A comparative evaluation of the laser technology with the traditional method of levelling was carried out to know Reduced 
Levels' (RLs), Standard Deviation (SD), Levelling Indices (LI), Soil-moisture Deviation (moisture SD) and Uniformity
Coefficient $\left(\mathrm{U}_{\mathrm{c}}\right)$. The levelling indices were calculated using the formula given by Agarwal and Goel (1981).

$$
\text { Leveling index }=\frac{\sum \text { Numerical difference between the designed and existing grid levels }}{\text { Number of grid points }}
$$

The moisture contents at grid points in fields were measured and its distribution uniformity or Uniformity co-efficient was calculated using Christiansen formula (Michael, 2011).

$$
C u=100\left[1-\frac{\sum X}{m n}\right]
$$

Where,

$\mathrm{Cu}=$ Uniformity Coefficient or Moisture distribution Uniformity in \%

$\mathrm{m}=$ Average value of all moisture contents in $\%$

$\mathrm{n}=$ Total number of grid points

$\mathrm{X}=$ Numerical deviations of individual observations or grid moisture content from the average moisture content.

After assessing the many beneficial aspects of laser leveller, the Laser technology was demonstrated to the several farmers during Krishimelas and through demonstrations and field level trainings held during every year for helping to farming community. Fig. 1 shows the working of Laser technology in agricultural fields. Extension activities like demonstrations during Krishimela and trainings were taken up to popularize laser technology among paddy growing farmers of Hyderabad-Karnataka region (Fig. 2). With extension efforts, the number of farmers trained with demonstration of laser levelling technology and the area levelled by laser technology increased rapidly. UAS Raichur provided these laser guided land levellers to needy farmers on nominal rates for the promotion and popularization of Laser levelling. So far about 30000 acres of paddy fields are levelled with Laser technology. This would a successful and significant contribution of State Agriculture universities in the field of Precision Agriculture if it is be taken forward to other irrigation command areas of Karnataka for enhanced water productivity.

\section{Results and Discussion}

After the fields were levelled traditionally and with LASER technology (both methods of levelling), the results showed that considerably lower values of standard deviations of reduced levels when the fields were graded by use of the laser technology Which indicates that lower the undulations in the Laser Levelled field as compared to traditional levelling field (Table 1). Similarly, the considerable decrease in the standard deviations (SD) of RLs as well as levelling indices (LI) and uniform distribution of the soil moisture over the entire field was achieved with laser technology (Anuraja et. al., 2013). This showed that the precision and quality of levelling operation increased with laser technology for land development where as it depended on individual's skills of the operator in traditional land development. The uniformity of soil-moisture distribution on the laser levelled and traditional levelled fields were found as $93.63 \%$ and $74.41 \%$, respectively. Laser technology has been demonstrated in krishimelas and popularized by several field level trainings (Table 2). The studies on laser technology for land development in the jurisdiction of the University of Agricultural Sciences,(UAS) Raichur highlighted considerable reduction in drudgery of land levelling, higher levelling 
index, uniformity in soil-moisture distribution (95-98\%), irrigation time and water saving (25-30\%). Similar findings were reported by Rajput et al., (2004), Jat et al., (2005) and Aggarwal et al., (2010). After demonstrations to the several farmers of Upper Krishna Project (UKP) and Tungabhadra Project (TBP) during Krishimelas, in farmers' fields and through field level adoption of Laser technology for land development, it was observed that 25 to 35 per cent increase in paddy yield as well as saving in man power and 30 to 40 per cent saving in energy requirement in paddy cultivation (Table 3 ). So far more than 40 units of Laser land levellers being owned by the farmers of UKP and TBP areas indicating it as the farmer friendly technology for paddy cultivation.

Table.1 Research findings from fields before and after adoption of Laser land levelling technology for land development

\begin{tabular}{|l|l|l|}
\hline \multirow{2}{*}{ Parameters } & \multicolumn{2}{|c|}{ Values } \\
\cline { 2 - 3 } & Laser levelling & Traditional levelling \\
\hline Length of field, $\mathrm{m}$ & 100 & 100 \\
\hline Width of field, $\mathrm{m}$ & 60 & 60 \\
\hline Area of field, $\mathrm{m}^{2}$ & 6000 & 6000 \\
\hline $\begin{array}{l}\text { Standard deviation, cm before levelling (10 } \\
\text { mx10 m grids) }\end{array}$ & 21.47 & 22.63 \\
\hline $\begin{array}{l}\text { Standard deviation, cm after levelling } \\
\text { mx10 m grids) }\end{array}$ & 3.07 & 12.04 \\
\hline levelling index before levelling, cm & 9.67 & 11.69 \\
\hline levelling index after levelling, cm & 1.22 & 6.69 \\
\hline Uniformity coefficient, \% & 93.63 & 74.41 \\
\hline
\end{tabular}

Table.2 Trainings /demonstrations on Laser land levelling technology to paddy farmers

\begin{tabular}{|c|l|c|c|l|}
\hline $\begin{array}{c}\text { Sl. } \\
\text { No. }\end{array}$ & \multicolumn{1}{|c|}{ Place /Event } & Year & Date & $\begin{array}{c}\text { No. of } \\
\text { farmers }\end{array}$ \\
\hline $\mathbf{1}$ & UAS Raichur Training & $2011-12$ & 30.01 .2012 & 88 \\
\hline $\mathbf{2}$ & UAS Raichur, Krishimela & $2012-13$ & 01.12 .2012 & 818 \\
\hline $\mathbf{3}$ & UAS Raichur, Krishimela & $2013-14$ & 05.10 .2013 & 1070 \\
\hline $\mathbf{4}$ & Field demonstration at Puchaladinni, Tq. Raichur & $2013-14$ & 24.08 .2013 & 60 \\
\hline $\mathbf{5}$ & UAS Raichur, Krishimela & $2014-15$ & 14.11 .2014 & 451 \\
\hline $\mathbf{6}$ & University Level Training at Sindhanur & $2014-15$ & 14.02 .2015 & 39 \\
\hline $\mathbf{7}$ & UAS Raichur, Krishimela & $2015-16$ & 30.01 .2016 & 513 \\
\hline $\mathbf{8}$ & UAS Raichur, Krishimela & $2016-17$ & 05.11 .2016 & 378 \\
\hline
\end{tabular}


Table.3 Overall advantages of Laser land levelling technology (with feedback from farmers)

\begin{tabular}{|c|c|}
\hline Particulars & Values, $\%$ \\
\hline Increase in cultivable land & 3 to 5 \\
\hline Saving in fertiliser usage & 25 to 30 \\
\hline Water saving & 25 to 30 \\
\hline Labour saving & 45 to 50 \\
\hline Increase in yield & 25 to 35 \\
\hline Energy saving & 30 to 40 \\
\hline
\end{tabular}

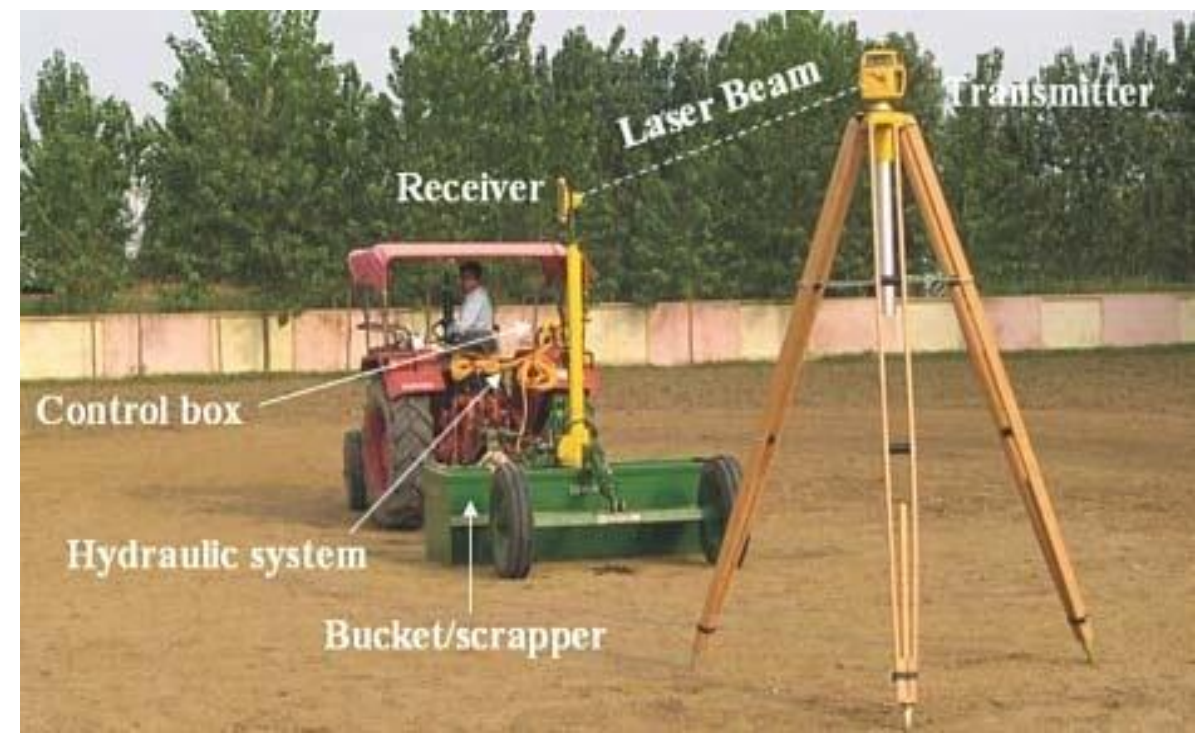

Fig.1 Working of Laser land levelling Technology for Agriculture land development
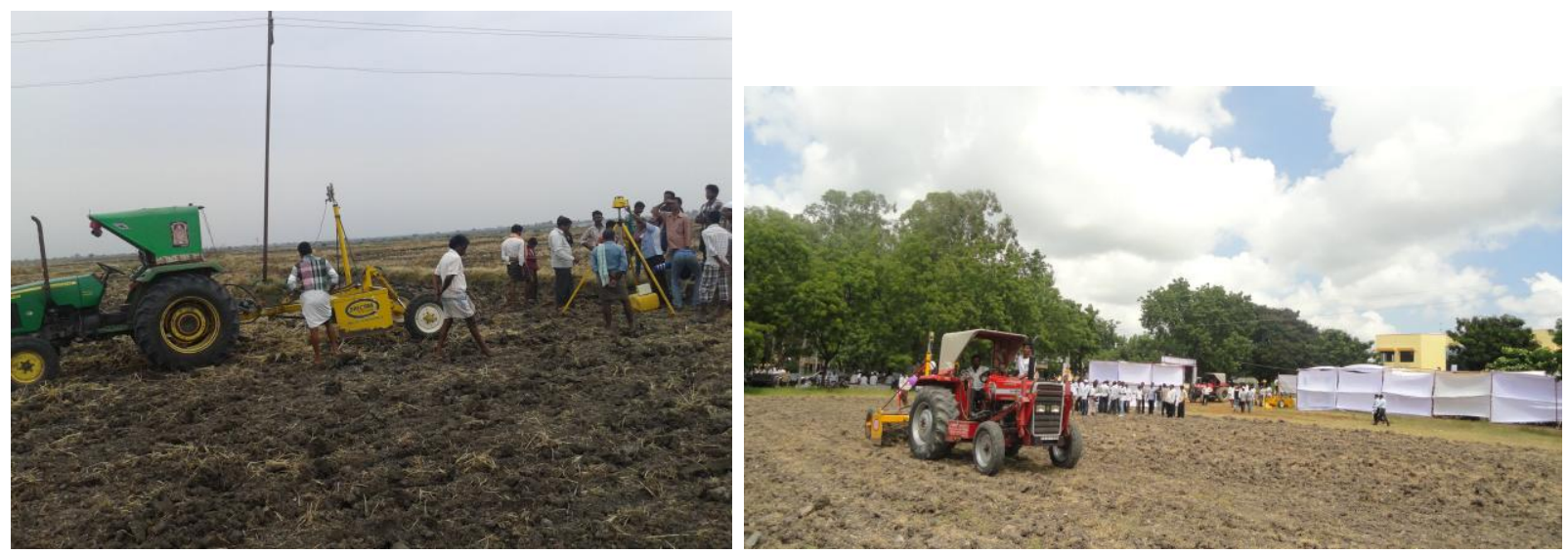

Fig.2 Trainings and demonstrations of Laser land levelling technology

After encouraged by the beneficial impacts of this Laser levelling technology in different states of the Northern India the number of Laser levellers increased more than 13000 but in Karnataka these are still less than 50 until now. So there is huge opportunity to popularise this farmer friendly technology in all the irrigation command areas of Karnataka. The overall benefits of Laser land levelling technology for levelling are increase 
in cultivation area, yields and water use efficiency, reduction in time and water requirement for Irrigation, better and uniform crop establishment, saving of fuel and energy, easy crop management as well as decreased drudgery.

\section{Acknowledgement}

Authors are grateful to staff of College of Agricultural Engineering and officers of University of Agricultural Sciences, Raichur in helping to initiate and popularize this Laser land levelling technology in farmers' fields with all support, cooperation and encouragement. Authors also express their gratitude to the farmers who came forward in demonstration and adoption of Laser land levelling technology and sharing their opinions.

\section{References}

Agarwal, M.C. and Goel, A.C., 1981, Effect of field levelling quality on irrigation efficiency and crop yield. Journal of Agricultural Water Management, 4: 457-464.

Aggarwal, R., Samanpreetkaur and Amarjeet Singh., 2010, Assessment of saving in water resources through precision land levelling in Punjab. Journal of Soil and Water Conservation, 9(3): 182-185.

Anuraja, B., Kanannavar, P. S., Balakrishnan, P., Pujari, B. T. and Hadimani, M. B., 2013, Laser guided land leveller for precision land development. Karnataka Journal of Agricultural Sciences, 26(2): 271-275.

Jat, M. L., Sharma, S. K., Gupta, R. K., Kuldeep, S. and Parvesh, C., 2005, Laser land levelling- The Precursor Technology for Resource Conservation in Irrigated Ecosystem of India, Conservation Agriculture-Status and Prospects. Centre for Advancement of Sustainable Agriculture, New Delhi. pp. $145-154$.

Michael, A. M., 2011, Irrigation Theory and practice, second edition, Vikas publishing House Pvt. Ltd., Noida201301 (UP), India, pp: 398-399.

Rajput, T. B. S., Patel, N. and Agrawal, G., 2004, Laser levelling- a tool to increase irrigation efficiency at field level. Journal of Agricultural Engineering, 41(1): 20-25.

Rickman, J.F., 2002, "Manual for laser land leveling". Rice-Wheat Consortium Technical Bulletin Series 5. New Delhi-110 012, India: Rice-Wheat Consortium for the Indo- Gangetic plains, p. 24.

Santhana Bosu, S. 2010, Engineering Interventions for Food Security in Rainfed Areas. Lead Paper presented in the National Seminar on Engineering Agriculture for Evergreen revolution held at S.V.U. Tirupati by ISAE (AP Chapter) during 24-25 September.

\section{How to cite this article:}

Kanannavar, P. S., B. D. Premanand, B. Subhas, B. Anuraja and Basavaraj Bhogi, P. 2020. Laser Land Levelling- An Engineering Approach for Scientific Irrigation Water Management in Irrigation Command Areas of Karnataka, India. Int.J.Curr.Microbiol.App.Sci. 9(05): 23932398. doi: https://doi.org/10.20546/ijcmas.2020.905.272 